\title{
Phytochemistry, nutritional composition, and pharmacological activities of Thaumatococcus daniellii (Benth): a review
}

\author{
Olumide Fadahunsi ${ }^{1 *}$, Peter I. Adegbola ${ }^{1}$, Sinbad O. Olorunnisola ${ }^{1}$, Oluseyi A. AKinloye ${ }^{2}$ \\ ${ }^{1}$ Ladoke Akintola University of Technology, Ogbomoso, Nigeria and Federal University of Agriculture, Ogun State, Nigeria \\ ${ }^{2}$ Federal University of Agriculture, Abeokuta, Nigeria
}

\begin{abstract}
Thaumatococcus daniellii (Benth) is a member of a diverse family of plants known as Marantaceae. Native to the tropical forest zones of West Africa, the plant is globally famous for its low calorie, nondiabetic natural sweetener called thaumatin found in its aril. $T$. daniellii thrives in deep shade, and it is used locally as a taste modifier and for preparing fish traps, ornamental bags, and mats. Organs of the plant are used in folkloric medicine as a laxative and in treating ailments such as mental disorders, high blood sugar, and lung diseases. The seeds and leaf sap are potent as an antidote against snake venom and bee stings and for preventing dystocia and prolonged child labor. Proximate analysis, phytochemical screening, and gas chromatography-mass spectrophotometry revealed that the plant contains proteins, important macro- and microelements (calcium, magnesium, zinc, sodium, phosphorus, potassium, iron, and manganese), and abundant active principles and compounds such as squalene tannin, alkaloids, saponins, epicatechin, steroids, phlobatannins, anthraquinones, terpenoids, spartein, ribalinidine, rutin, phytic acid, and kaempferol. Biological activities include hypolipidemic, antihyperglycemic, antioxidant, insecticidal, bioremediative, and antimicrobial activities. T. daniellii could be used in the formulation of food supplements and drug development.
\end{abstract}

Key words: Thaumatococcus daniellii, phytochemistry, nutritional composition, pharmacological activities, ethnomedicinal uses

\section{Introduction}

Since antiquity, long before the advent of allopathic drugs, herbs and medicinal plants have been germane and significant in the management and treatment of many human ailments and pathological conditions (Gourhan, 1975; Falodun, 2010). Over 55,000 species of plants have been reported to be used singly or in combination in phytomedicine (Pan et al., 2014). Even with the proliferation and discovery of many conventional and synthetic drugs, plants are still recognized as important in healthcare programs and systems of many countries. Many pharmaceutical and research institutes are embracing and investing in herbs and natural products as a reliable source for drug development and discovery
(WHO, 1998; Seidl, 2002; Corson and Crews, 2007; Schmidt et al. 2007; Li and Zhang, 2008).

Thaumatococcus daniellii (Benth) is a perennial, monocotyledonous, self-propagatory plant that belongs to the Marantacea family (Table 1) (Jennings et al., 2001). It is an inherently wild, shade-tolerant plant originating from sub-Saharan Africa from Sierra Leone to Democratic Republic of Congo (DRC). It is also reported to exist in Australia, Singapore, Angola, the Central African Republic, Princes' Island, Uganda, and Indonesia (Yeboah et al., 2003). An increased demand and use of the plant for its household, presumed medicinal and industrial applications, and economic value has led to an upward spiral in its cultivation. There is no paucity of

\footnotetext{
* Corresponding author: Ladoke Akintola University of Technology, Ogbomoso, Nigeria and Federal University of Agriculture, Ogun State, Nigeria; e-mail: fadahunsiolumide5@gmail.com
} 
Table 1. Taxonomical classification of Thaumatococcus daniellii

\begin{tabular}{l|l}
\multicolumn{1}{c|}{ Kingdom } & \multicolumn{2}{c}{ Plantae } \\
\hline Subkingdom & Viridiplantae \\
\hline Superdivision & Embrophyta \\
\hline Division & Tracheophyta \\
\hline Subdivision & Spermatophytina \\
\hline Class & Magnoliopsida \\
\hline Order & Zingiberales \\
\hline Superorder & Lilianae \\
\hline Family & Marantaceae \\
\hline Genus & Thaumatococcus \\
\hline Species & Thaumatococcus daniellii (Benn.) \\
\hline
\end{tabular}

scientific data on the nutritional and pharmacological value of oils, hexane fraction, and extracts obtained from T. daniellii. Most of these data can be found in scholarly articles published in highly prestigious academic journals (Elemo et al., 1999; Adeogun et al., 2016; Shalom et al., 2018).

\section{Botanical description and taxonomy of T. daniellii}

T. daniellii, also called as sweet prayer plant and African serendipity berry, is commonly referred to by its African vernacular names, including Katemfe in Sierra Leone, Nzilizili in Democratic Republic of the Congo (Termote, 2011), and Adundunmitan, Ewe eran, and Ewe moi-moi in South Western Nigeria. It is also known as Iwee and Mfang Aya among the Igala and Ibiobio tribes of North Central and South Southern Nigeria, respectively (Essien et al., 2016; Ukwubile et al., 2017). With only one species in the entire West Africa, T. daniellii is a large rhizomatous, flowering herb and grows up to approximately $40 \mathrm{~cm}$ in height (Hutchinson and Daziel, 1963). The fruits are pyramidal in shape and have dark red-brown hue when truly ripe (Fig. 1). At maturity, 3-4 black, hardened, and strong seeds (6-30 g) wrapped in a gummy thin, yellow basal aril are contained in the fruit (Tomlison, 1961; Most et al., 1978; Lim, 2012). Depending on the number of years lived and the habitat, T. daniellii stalks are slender and long and can grow up to $2-3 \mathrm{~m}$, each carrying a lone sturdy, eggshaped leaf $(60 \mathrm{~cm}$ long and $40 \mathrm{~cm}$ wide, Fig. 2) and violet colored flowers (Makinde and Taiwo, 2004). The aril contains a nontoxic, nondiabetic, low-calorie, ex-

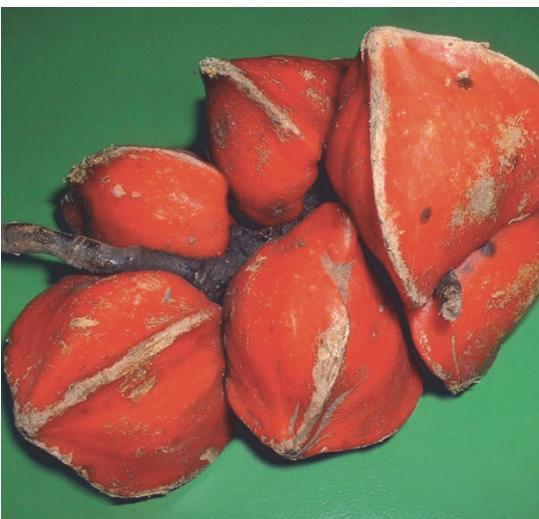

Fig.1. Fruits of $T$. daniellii

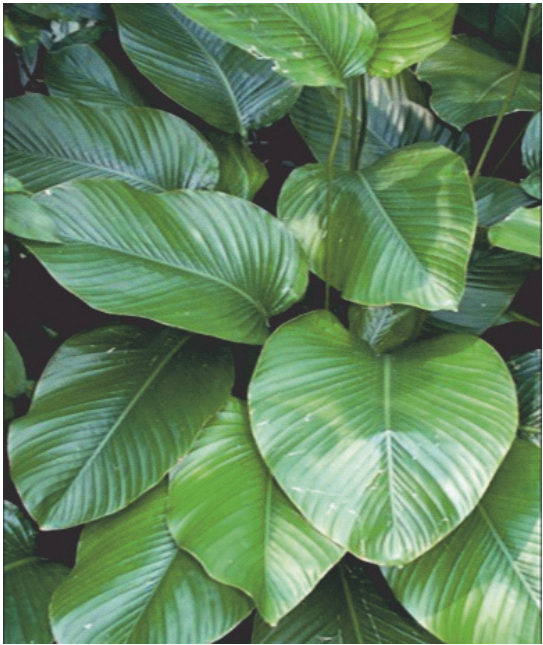

Fig. 2. T. daniellii leaves

tremely sweet, hydrophilic protein known as thaumatin (22 $000 \mathrm{Da}$ ) (Watson and Dallwitz, 2000). Its structure contains a single chain of 207 amino acid residues and eight disulfide bonds with an isoelectric point of 11.5-12.5 (Gloria, 2003). Antecedently, a monomeric cysteine protease (thaumatopain) of molecular weight (MW) of $30000 \mathrm{Da}$ and optimum $\mathrm{pH} 8.0$ was purified from the arils (Cusack et al., 1991; Stephen et al., 1994). Furthermore, protease isolated and purified from the pulp of $T$. daniellii was found to have an optimum temperature of $35^{\circ} \mathrm{C}$ and $\mathrm{pH} 7$ (Raimi et al., 2011).

\section{Folkloric and ethnomedicinal uses of T. daniellii}

Different parts of $T$. daniellii are used in traditional and folkloric management of some diseases and ailments. The roots and fruits are used in Democratic Republic of the Congo to treat women in labor with dystocia and childbirth complications. The seeds and leaf 
saps have been documented as an emetic agent in treating lung diseases and as an antidote against bee stings, snake bites, and venom, while the fruits and pulps are used in child weaning and as a laxative (Termote, 2012; Adeyemi et al., 2014; Shalom et al., 2014). Leaf and root saps are used as tranquilizing agents for treating mental and psychiatric disorders (Shalom et al., 2014). Different ethnobotanical surveys have reported the folkloric usefulness of $T$. daniellii in the traditional management of high blood sugar and diabetic-related disorders (Coolborn and Adegbemisipo, 2008; Olorunnisola et al., 2016). In Gabon, T. danielli is planted and cultured for its presumed fetish and magical potential (Mansfeld, 1986).

The leaves are widely used in wrapping cooked rice and moi moi during cooking in Ghana and Nigeria. The plant has also gained wide acceptance in some parts of North and South America because of its exotic and flavor enhancing property (Thorn, 2004). The petioles are used in weaving mats and baskets, whereas bakeries, local wine industries, and confectionaries use thaumatin as a flavor and taste modifier (Onwuema et al., 1979; Franke, 1985; Abbiw, 1990; Zemanek and Wasserman, 1995; Wiersema and Leon, 1999; Elemo et al., 2011). Because of worldwide popularity and international and industrial approval of thaumatin as a natural sweetener, export of the plant from West African cities and villages has led to immense economic benefits of up to US $\$ 17000$ in foreign exchange yearly (Yeboah et al., 2003; Waliszewski et al., 2005; Arowosoge and Popoola, 2006; Chiech, 2008; Boadi et al., 2014).

\section{Phytochemistry of T. daniellii}

Plants are abundant sources of phytochemicals that are needed for survival and protection against predators (Oz and Kafkas, 2017; Choudhari et al., 2020). Results from animal and cell culture studies and consumption of these phytonutrients by humans have demonstrated that antioxidants afford considerable protection against free radicals and attenuate the progression of degenerative diseases such as cancers (Chu et al., 2002; Corson and Crews, 2007; Chahar et al., 2011). Different classes of bioactive principles and secondary metabolites of plant origin have been implicated for their potential to induce a cascade of biological and pharmacological activities (Suffredini et al., 2004; Boots et al., 2008). For instance, insecticidal activities of plants such as Cymbopogon citratus, Citrullus colocynthis, Curcuma longa, Allium sativum, Cannabis indica, and Artemisia argyi have been attributed to the presence of compounds such as caryophylleneonides, $\alpha$-bisabolol, dronabinol, methyl allyl disulfide, diallyl trisulfide, erucylamide, and octasiloxane hexamethyl (Ali et al., 2004; Phasomkusolsil and Soonwera, 2011; Hikal, 2017; Ahmed et al., 2020). Moreover, the importance of natural flavoring compounds such as saffron from Crocus sativus, carvone, $\alpha$-lonone, eucalyptol, and menthol has been previously reported (Maggi et al., 2009; Lorenzo and Eugeniol, 2011). Alpinia gagnepainii, Phrynium imbricatum, and Hibiscus sabdariffa are among other plants that are used traditionally as food colorants and preservatives (Gyamfi and Aniya, 2002; Salavkar et al., 2011; Quang et al., 2018; Zhou et al., 2018a; Fadahunsi and Adeyina, 2019). Extensive studies have been conducted to determine the qualitative and quantitative phytochemical constituents of T. daniellii, with many studies confirming the presence of some compounds with biological importance (Table 2). Previous studies by Elemo et al. (1999), Elemo et al. (2001), Oforibika et al. (2017), and Oyeleke et al. (2017) reported that the pericarp and seeds contain high content of phytic acid, tannins, saponins, and polyphenol. Tandemly, quantitative phytochemical analyses of extracts of fruit (pericarp and seeds), leaf, and root revealed the presence of alkaloids, tannins, saponins, flavonoids, phlobatannins, anthraquinones, phytate, phenol, steroids, and terpenoids in high quantities (Adeyemi et al., 2014; Ndukwe et al., 2014; Shalom et al., 2014; Adeogun et al., 2016; Oke et al., 2016; Oboh et al., 2016; Hamid et al., 2017; Ogoloma et al., 2017). By using gas chromatography-flame ionization detector (GC-FID), gas chromatography-mass spectrophotometry (GC-MS), and high-performance liquid chromatography (HPLC), fingerprinting of the essential oils and crude extract of the rhizome and leaf has shown arrays of secondary metabolites and bioactive principles (Shalom et al., 2014; Adeogun et al., 2016; Oboh et al. 2016; Ogoloma et al. 2017). Notable among these compounds are 4-hydroxy carbonyl-2-oxoethyl triphenylphosphonium bromide, 1-methyl-3-isoprophylbenzene, hendecane, 1,3,5-trimethylbenzene, 3,3-dimethylbutyrophenone, $n$-nonane, isodecane, 4-methyldecane, lunamarine, ribalinidine, kaempferol, rutin, oxalate, catechin, anthocyanins, epicatechin, and sparteine (Table 3) (Shalom et al., 2014; Adeogun et al., 2016; Oboh et al., 2016; Ogoloma et al., 2017). In another study, Abiodun et al. (2014) reported 
Table 2. Biological and pharmacological activities of some identified compounds from $T$. daniellii

\begin{tabular}{|c|c|c|}
\hline Compounds & Biological activity & References \\
\hline Anthocyanins & $\begin{array}{l}\text { anti-radical, anti-hyperglycemic, } \\
\text { anticancer }\end{array}$ & $\begin{array}{l}\text { Huang et al. (2014); Lee et al. (2015); Samadder et al. (2017); } \\
\text { Thibado et al. (2018) }\end{array}$ \\
\hline Anthraquinones & $\begin{array}{l}\text { anticancer, anti-acne, antifungal, } \\
\text { antibacterial, anti-inflammatory, } \\
\text { anticoagulant, neuro therapeutic }\end{array}$ & $\begin{array}{l}\text { Huang et al.(2007); Gan et al. (2008); } \\
\text { Wuthi-udomlert et al. (2010); Khan et al. (2011); } \\
\text { Seo et al. (2012); Jackson et al.(2013); Shrestha et al.(2014); } \\
\text { Shrestha et al. (2015) }\end{array}$ \\
\hline Catechins & $\begin{array}{l}\text { anti-cancer, anti-inflammatory, } \\
\text { antioxidant }\end{array}$ & $\begin{array}{l}\text { Murakami et al. (2002); Fang et al. (2003); } \\
\text { Hussain et al. (2005); Fang et al. (2007) }\end{array}$ \\
\hline Geranylgeraniol & $\begin{array}{l}\text { testosterone and peroxisome } \\
\text { proliferator-activated receptor } \gamma \\
\text { (PPAR } \gamma \text { ) enhancement }\end{array}$ & Ho et al. (2016); Mastubara et al. (2018) \\
\hline Hexadecanoic acid & cytotoxic & Ravi and Krishnan (2017) \\
\hline Kaempferol & $\begin{array}{l}\text { cytotoxic, antioxidant, } \\
\text { anti-inflammatory }\end{array}$ & $\begin{array}{l}\text { Leung et al. (2007); Hamalaina et al. (2007); } \\
\text { Vellosa et al. (2011); Boadi et al. (2016) }\end{array}$ \\
\hline Phytol & antinociceptive, antioxidant & Santos et al. (2013) \\
\hline Rutin & $\begin{array}{l}\text { cardio-protective, neuro-protective, } \\
\text { antidiabetic, nephroprotective }\end{array}$ & $\begin{array}{l}\text { Stanley and Kamalakkannan (2006); Yang et al. (2008); } \\
\text { Annapuma et al. (2009); Gulpinar et al. (2012); } \\
\text { Hao et al. (2012) }\end{array}$ \\
\hline Saponins & $\begin{array}{l}\text { hypocholesterolemic, immunodulatory; } \\
\text { anti-inflammatory, cytotoxic }\end{array}$ & Matsuura (2001); Sun et al. (2014); Lin et al. (2016) \\
\hline Spartein & hypoglycemic; anti-convulsant & Kozlowska et al. (2007); Vargas and Ceja (2016) \\
\hline Squalene & $\begin{array}{l}\text { anti-hyperlipidemia, antioxidant, } \\
\text { anti-atherosclerosis }\end{array}$ & $\begin{array}{l}\text { Motawi et al. (2010); Gabas-Rivera et al. (2015); } \\
\text { Kumar et al. (2016) }\end{array}$ \\
\hline Terpenoids & anticancer, antibacterial & Dorman and Deans (2000); Huang et al. (2012) \\
\hline
\end{tabular}

that GC-MS chromatogram revealed cyclopropane, nonyl-5-tetradecene, and 7-tetradecene to constitute the highest percentage $(79.60 \%)$ of the 24 compounds of essential oil of the fruit tissue and seeds of $T$. daniellii. Conversely, on the basis of the results of analysis with thin layer chromatography, the presence of additional compounds (cardenolides and steroidal nucleus) in the leaf crude extracts was reported (Ojekale et al., 2013). Hydrodistillation of the leaves of $T$. daniellii and analysis of the oil show the presence of 21 volatile constituents (Ojekale et al., 2013). A wide range of compounds such as polysiloxanes, terpenoids, aromatics, long-chain hydrocarbons, polysteroids, alcohols, aldehydes, ketones, fatty acids, and their esters were discovered using GC and GC-MS analysis, with octadecamethyl cyclononasiloxane (48.3\%), phytol (12.9\%), and 6,10,14-trimethyl-2-pentadecanone $(9.3 \%)$ being the dominant compounds (Ojekale et al., 2007). In congruence, GC-MS analysis also recorded the bioavailability of 22 compounds in the essential oil of the leaf, among which are oleic acid and geranylgeraniol (Omisope et al., 2016). Compounds such as squalene, tetracontane, n-hexadecanoic acid, phytol, L-ascorbic acid, and octadecanoic acid (Table 3) were discovered through GC-MS examination as constituents of the hexane, ethyl acetate, and methanol extracts of the leaf (Hamid et al., 2017).

\section{Proximate and nutritional composition of morphological organs of T. daniellii}

There is overwhelming scientific information on the nutritional composition of various morphological organs of $T$. daniellii, which can be correlated to its nutritional and medicinal benefits. A pioneer study by Adesina and Higginbotham (1977) confirmed that arabinose, glucoronic acid, xylose, and 4-O-methyl glucoronic acid exist in the polysaccharide gel extracted from the fruit of T. daniellii. Furthermore, extensive elemental analyses have shown that many macro- and microelements are present in the different organs of the plant (Shalom et al., 2014; Sotande and Oluwadare, 2014). It was revealed that the stalk of $T$. daniellii contains phosphorus 
and nitrogen (Sotande and Oluwadare, 2014). The contents of potassium, iron, manganese, and copper were revealed using flame atomic absorption spectrometer (AAS) (Shalom et al., 2014; Sotande and Oluwadare, 2014). Potassium and iron were considered as the main metals contributing to the physiological development of the plants (Shalom et al., 2014; Sotande and Oluwadare, 2014). It has been shown that the arils, fruits, and leaves are good sources of sodium, calcium, magnesium, and phosphorus (Shalom et al., 2014, Ojo et al., 2017, Osuocha et al., 2018). Phosphorus (0.37 g) and calcium $(0.34 \mathrm{~g})$ were reported to be the most abundant elemental constituents per $100 \mathrm{~g}$ of the extract. On the other hand, the concentrations of iron and zinc were low in the leaves and fruits, respectively. Vitamins (A, B1, $\mathrm{B} 3, \mathrm{~B} 5, \mathrm{~B} 6, \mathrm{~B} 12$, and $\mathrm{C}$ ) have been reported to be present in the leaf and seed extract of the plant, with vitamin B12 as the most abundant one (Abiodun et al., 2014; Shalom et al., 2014; Oforobika et al., 2017; Osuocha et al., 2018). Proximate composition of 100 g per sample of aqueous extract of the leaf, fruit, and seed depicted a high content of carbohydrate (29.08\%) in the seed and fruit, while crude fiber was more abundant in the leaf (36.61\%). Fat (3.85\%), protein (19.01\%), and ash (10.60\%) were also present, while the highest moisture $(83.90 \%)$ content was detected in the seed extract (Ndukwe et al., 2014; Oforobika et al., 2017). Interestingly, proximate composition recorded for $T$. daniellii morphological organs were similar to that of some selected edible leafy vegetables (Table 4). Nutritional analysis of the fruit revealed that it contains calcium $(6.68 \%)$, magnesium (0.60\%), ash (5.80\%), fiber (0.41\%), protein $(19.01 \%)$, nitrogen $(3.04 \%)$, and hydrogen cyanide $(0.81 / \mathrm{kg})$ (Ndukwe et al., 2014). Defatted seed flour of $T$. daniellii was recorded to contain crude fiber (36.92\%), carbohydrate (40.07\%), and ash (8.17\%), while oleic $(42 \%)$, palmitic $(24 \%)$, and linoleic $(18 \%)$ acids were the main fatty acid constituents of the seed oil (Abiodun et al., 2014). To increase abundance, carbohydrate $(44 \%)$, protein $(33 \%)$, moisture $(12 \%)$, fiber $(5 \%)$, ash $(4.8 \%)$, and fat $(0.61 \%)$ were reported as the proximate composition of the aril of $T$. daniellii (Sotannde and Oluwadare, 2014). Fiber property examination of the stalk revealed that holocellulose (66.98\%) was the most dominant component, while $\alpha$-cellulose (38.51\%), crude fiber (32.61\%), lignin (13.29\%), and hemicellulose $(28.20 \%)$ were present in appreciable amounts. How-
Table 3. Structures of some identified compoumds from $T$. danielli

Compounds


Table 4. Comparative proximate composition of some edible leafy vegetables with $T$. daniellii

\begin{tabular}{l|c|c|c|c|c|c|l}
\hline \multicolumn{1}{c|}{ Plant } & $\begin{array}{c}\text { Ash } \\
{[\%]}\end{array}$ & $\begin{array}{c}\text { Carbohydrate } \\
{[\%]}\end{array}$ & $\begin{array}{c}\text { Fat } \\
{[\%]}\end{array}$ & $\begin{array}{c}\text { Moisture } \\
{[\%]}\end{array}$ & $\begin{array}{c}\text { Crude fiber } \\
{[\%]}\end{array}$ & $\begin{array}{c}\text { Protein } \\
{[\%]}\end{array}$ & References \\
\hline$T$. daniellii (Fruit) & 5.80 & 70.00 & 3.85 & 83.90 & 0.42 & 19.01 & Ndukwe et al. (2004) \\
\hline$T$. daniellii (Seed) & 8.17 & 40.07 & 2.32 & 10.39 & 36.92 & 2.14 & Abiodun et al. (2014) \\
\hline$T$. daniellii (Aril) & 4.79 & 44.17 & 0.61 & 12.20 & 5.20 & 33.03 & Ojo et al. (2017) \\
\hline$T$. daniellii (Leaf) & 10.60 & 31.25 & 0.90 & 5.16 & 36.61 & 14.88 & Oforobika et al. (2017) \\
\hline T. daniellii (Rhizome) & 6.20 & 18.75 & 1.80 & 17.27 & 48.98 & 7.00 & Oforobika et al. (2017) \\
\hline Solanium macrocarpon & 8.44 & 49.56 & 1.31 & 49.53 & 11.83 & 21.54 & Odoh et al. (2007) \\
\hline Moringa olifera & 5.13 & 43.78 & 2.63 & 71.73 & 19.25 & 20.51 & Sharma et al. (2012) \\
\hline Amaranthus hybridus & 16.43 & 25.56 & 2.31 & 53.53 & 10.93 & 18.84 & Odoh et al. (2007) \\
\hline Amaranthus viridis & 1.85 & 7.67 & 0.47 & 87.90 & 1.93 & 2.11 & Sharma et al. (2012) \\
\hline Vernonia amygdalina & 12.94 & 35.56 & 4.31 & 49.53 & 9.83 & 31.54 & Odoh et al. (2007) \\
\hline Gongronema latifolium & 16.74 & 39.56 & 1.31 & 49.53 & 11.83 & 29.54 & Odoh et al. (2007) \\
\hline Ocimum gratissimum & 27.44 & 40.56 & 2.91 & 31.53 & 15.03 & 41.54 & Odoh et al. (2007) \\
\hline Murraya koenigii & 12.04 & 56.56 & 6.21 & 49.53 & 4.43 & 13.34 & Odoh et al. (2007) \\
\hline
\end{tabular}

ever, ash $(2.79 \%)$ and silica $\left(\mathrm{SiO}_{2}\right)(0.85 \%)$ were found to be present in very low concentrations (Sotannde and Oluwadare, 2014).

Elemo et al. (1999) reported that the extracted oil from pericarp and seed was golden yellow in appearance and slightly solid at room temperature. The iodine number of the seed oil $(20.5 \mathrm{~g} / 100 \mathrm{~g})$ and pericarp oil $(34.1 \mathrm{~g} / 100 \mathrm{~g})$ was lower than that of palm oil $(48-56 \mathrm{~g} / 100 \mathrm{~g})$ and olive oil $(80-88 \mathrm{~g} / 100 \mathrm{~g})$ but higher than that of palm kernel $(14.23 \mathrm{~g} / 100 \mathrm{~g})$ and butter $(26.42 \mathrm{~g} / 100 \mathrm{~g})$. Conversely, the saponification value of the pericarp and seeds oils was lower $(154.4 \mathrm{mgKOH} / \mathrm{g}$ and $149.3 \mathrm{mgKOH} / \mathrm{g}$, respectively) than that of palm oil (196-202 mgKOH/g), coconut oil (250-264 mgKOH/g), and palm kernel $(245-255 \mathrm{mgKOH} / \mathrm{g})$. Free fatty acid composition of the pericarp and seed oil $(16.2 \%$ and 14.5\%) was lower than that of palm oil (37.6\%) and similar to that of palm kernel (14.6\%) (Weiss, 1983; Elemo et al., 1999). The refractive index, specific gravity, acid, saponification, peroxide, iodine, and free fatty acid value of the seed oil were reported to be $1.4,0.76,44.93 \mathrm{mg} / \mathrm{g}$, $190.08 \mathrm{mg} / \mathrm{g}, 11.00 \mathrm{mg} / \mathrm{g}, 60.34 \mathrm{mg} / \mathrm{g}$, and $22.58 \mathrm{mg} / \mathrm{g}$, respectively (Abiodun et al., 2014). In addition, from the results obtained from biological evaluation, it was inferred that the nutrient enhancing ability of the seed waste proteins was comparable to that of casein (Elemo et al., 2011).
T. danielliifruit improved the physicochemical and sensory property of "Kunun-Zaki" fermented nonalcoholic sorghum-based drink and also enhanced the shelf life of stored orange juice (Adeogun etal., 2017; Ojo etal., 2017).

\section{Pharmacological and biological activities of T. daniellii}

\section{Antioxidant activities of T. daniellii}

Increased production of reactive oxygen species (ROS) leading to disruption or an imbalance in the antioxidant defense system is referred to as oxidative stress (Stamati et al., 2011; Bhattacharya, 2015). Free radicals such as superoxide radical $\left(\mathrm{O}^{2-}\right)$ and hydrogen peroxide $\left(\mathrm{H}_{2} \mathrm{O}_{2}\right)$ are byproducts of mitochondrial electron transport and other metabolic processes (Shinde et al., 2012). They are, however, generated in high amounts from exogenous factors such as air pollution, cigarette smoking, excessive alcohol consumption, and ultraviolet radiation (Lobo et al., 2010). ROS have been implicated in the pathophysiology of several diseases such as cancer, atherosclerosis, and Parkinson's and Alzheimer's disorders (Parihar et al., 2009; Simone et al., 2010). Edible vegetables and medicinal plants are known to contain many secondary metabolites that can quench free radicals, upregulate the expression of enzymatic antioxidants, and thereby protect the cells and important biological molecules from oxidative damage (Baodi et al., 2006; Adegbola et al., 2020). 
According to Shalom et al. (2018), the daily administration of ethanol leaf extract (500-1500 mg/kg) for 14 days showed a significant $(P<0.05)$ increase in the concentration of liver and kidney superoxide dismutase (SOD) and reduced glutathione (GSH) in treated rats as compared to that in the control group. An in vitro antioxidant assay revealed that phenolic extract $(0-5 \mathrm{mg} / \mathrm{ml})$ of the leaves caused a significant $(P<0.05)$ dose-dependent $\mathrm{Fe}^{2+}$ chelation, lipid peroxidation, and malondialdehyde (MDA) production inhibitory activities. In the same study, a dose-dependent DPPH (1,1-diphenyl-2picrylhydrazyl) and hydroxyl radical $\left(\mathrm{OH}^{*}\right)$ scavenging activity with $\mathrm{EC}_{50}$ of 0.56 and $0.76 \mathrm{mg} / \mathrm{ml}$, respectively, was reported. According to Oboh et al. (2016) and Hamid et al. (2017), n-hexane and ethyl acetate extract $(1.95-1000 \mu \mathrm{g} / \mathrm{ml})$ of the leaves exhibited nonsignificant DPPH radical scavenging activities; however, the methanol extract $(1.95-1000 \mu \mathrm{g} / \mathrm{ml})$ inhibited 50\% DPPH radical scavenging activity at the concentration of $615.14 \mathrm{mg} / \mathrm{ml}$, which was statistically comparable to that of the control (ascorbic acid). In another study, DPPH and ferric reducing antioxidant potential (FRAP) of hexane and aqueous fractions of leaves at the concentration of $100-500 \mathrm{mg} / \mathrm{ml}$ were evaluated (Anyasor et al., 2016) The aqueous extracts demonstrated a significantly higher DPPH and FRAP inhibitory activity than hexane fraction (Anyasor et al., 2016). The observed higher activity is due to the higher phytochemical content in aqueous leaf fraction reported by Oke et al. (2016). Adedosu et al. (2017) reported that the aqueous leaf extract of T. daniellii at $100 \mathrm{mg} / \mathrm{kg}$ upregulated the antioxidant status of streptozotocin-induced diabetic rats. A significant increase was observed in GSH, SOD, and catalase activities in the extract-treated animals. Simultaneously, malondialdehyde (MDA) concentration was observed to be nearly the same when compared with that in the control and standard drug (glibenclamide)-treated animals. However, MDA was significantly lower than that in streptozotocin-induced untreated diabetic animals (Adedosu et al., 2017). Thus, this indicated the capacity of the plant extract to improve antioxidant defense and attenuate oxidative stress.

The ability of the essential oil of $T$. daniellii leaves to scavenge DPPH radicals and nitric oxide has been documented by Ojekale et al. (2013). The essential oil significantly and dose-dependently reduced the amount of DPPH radicals. At the concentration of $50 \mathrm{mg} / \mathrm{l}$, more than $80 \%$ of DPPH radicals were inhibited $\left(\mathrm{IC}_{50}\right.$ value of $26.3 \mathrm{mg} / \mathrm{l})$. This observed activity was relatively higher than that of butylated hydroxyanisole, butylated hydroxytoluene, ascorbic acid, and $\alpha$-tocopherol with $\mathrm{IC}_{50}$ values of $36.1,35.9,36.8$, and $41.7 \mathrm{mg} / \mathrm{l}$, respectively. In addition, a dose-dependent nitric oxide scavenging activity (78.5\%) higher than that of ascorbic acid and $\alpha$-tocopherol was shown by the essential oil. It was inferred that the essential oil of $T$. danielli quenches free radicals and is a good source of natural antioxidants, which can prevent lipid peroxidation, oxidative stress, and metabolic disorders.

Nwonuma et al. (2016) evaluated the effect of $T$. $d a$ niellii leaf extract in rats exposed to a single daily dose of potassium bromate $\left(\mathrm{KBrO}_{3}\right)(0.5 \mathrm{ml}$ of $10 \mathrm{mg} / \mathrm{kg})$ for 2 weeks. It was reported that treatment with different concentrations of the leaf extract protected against cellular degeneration of the testes and buoyed antioxidant enzyme activities. Furthermore, there was a $20 \%$ decrease in MDA concentration of the leaf extract-treated animals, and a significant increase in GSH and SOD activities was also recorded.

Shalom et al. (2017) concluded that $T$. daniellii seeds are a source of natural antioxidant and may be used further for their pharmacological potential. Their study showed that 14 days administration of 500,1000 , and $1500 \mathrm{mg} / \mathrm{kg}$ seed ethanol extract of $T$. daniellii caused an increased hepatic SOD and GSH concentration. No significant effect on renal SOD activity and GSH concentration was observed, but a significant $(P<0.05)$ increase in renal GSH concentration was demonstrated at $1500 \mathrm{mg} / \mathrm{kg}$ extract concentration. T. daniellii seed had no effect on the level of hepatic thiobarbituric acid reactive substances (TBARS). However, a significant increase was observed in renal TBARS level. The authors concluded that the observable increase in SOD (28.17 $\mathrm{U} / \mathrm{mg}$ protein) and $\mathrm{GSH}(20.32 \mathrm{mM} / \mathrm{mg}$ protein $)$ after the administration of $T$. daniellii seeds may be due to the synergistic stimulatory effects of various active components present in the seeds, while the increased renal MDA content might be related to high oxalate concentrations in the seeds (Noonan and Savage, 1999).

\section{Hepatoprotective activity and toxicological studies on T. daniellii}

The recent surge in the use of medicinal plants and products, especially in developing nations, is based on the premise that herbal medicine is readily available, 
cheap, and less toxic. A noteworthy finding is that the consumption of medicinal plants at high doses can induce injury to vital organs such as the liver and kidney (Chikezie et al., 2015). Biochemical parameters such as alanine aminotransferase (ALT), aspartate aminotransferase (AST), total bilirubin, and alkaline phosphatase (ALP) in the blood can be measured to determine the functional integrity of the liver (Satyanarayana and Chakrapani, 2007). Significant changes in the concentration of AST, ALT, and ALP singly or in combination may suggest physiological changes in response to toxic plant extracts or materials (Howida, 2016; Mumoli et al., 2016). Additionally, the toxicity of many compounds is commonly extrapolated from the concentration that can cause $50 \%$ mortality in the tested population (median lethal dose or $\left.\mathrm{LD}_{50}\right)$. Considering the aforementioned risks associated with the indiscriminate consumption of medicinal plants, various extracts and fractions of morphological organs of $T$. daniellii were evaluated in many toxicological studies. As reported in the study of Ogoloma et al. (2007), a 4-week intraperitoneal administration of the methanol leaf and root extract of $T$. $d a-$ niellii at $100-500 \mathrm{mg} / \mathrm{kg}$ doses in Wistar rats revealed the $\mathrm{LD}_{50}$ value to be 330 and $250 \mathrm{mg} / \mathrm{kg}$, respectively. Findings from this study showed that the methanol leaf extract of $T$. danielli in low and high doses had no significant effect on AST. Furthermore, a statistically nonsignificant elevation in ALT level was observed. There was an observable nonsignificant change in conjugate bilirubin, which was suggestive of intact liver function. However, a noticeable increase in alkaline phosphatase (ALP) activity was observed after 4 weeks of leaf extract administration. However, Emudainohwo et al. (2015) reported an $\mathrm{LD}_{50}$ value of above $6000 \mathrm{mg} / \mathrm{kg}$ for the leaf extract of $T$. daniellii.

Okafor et al. (2019) examined the hepatotoxic characteristic of the aqueous and methanol leaf extract $(200 \mathrm{mg} / \mathrm{kg})$. The aqueous extract caused a nonsignificant increase in the activity of ALT (5.43 IU/1), AST (16.93 IU/1), and ALP (160.70 IU/1). In contrast, the methanol extract caused a significant elevation of ALT (13.15 IU/l), AST (22.84 IU/l), and ALP (170.40 IU/l) levels, and the histological observation of the liver tissues showed inflamed hepatocytes with enlargement of the central vein, which was suggestive of derangement in the normal architecture of the liver tissue. Hence, Okafor et al. (2019) suggested that drug development protocols involving $T$. daniellii leaf should preferably use water as an extracting solvent.

As stated by Iheagwam et al. (2017), a significant decrease in the AST concentration of ethanol seed extract $(1500 \mathrm{mg} / \mathrm{kg})$ )-fed rats was observed. Despite this high dose exposure, a nonsignificant effect on total bilirubin $(17.73 \mu \mathrm{mol} / \mathrm{l})$ and direct bilirubin $(26.41 \mu \mathrm{mol} / \mathrm{l})$ concentration was concomitantly observed. The extract showed a better effect on these indices when compared with the standard drug (vitamin C). Hepatoprotective ability of the seed extract was further corroborated from the histological analysis, which revealed an absence of nontoxic symptoms and intact liver membrane integrity. In addition, Nwonuma et al. (2016) reported an absence of testicular cellular degeneration in the leaf extracttreated animals compared to that in the $\mathrm{KBrO}_{3}$-treated group. Moreover, the results obtained from the daily administration of $500 \mathrm{mg} / \mathrm{kg}$ acetaminophen for 4 weeks indicated that the leaf methanol extract-treated animals exhibited a significantly reduced total albumin $(0.80 \mathrm{mg} / \mathrm{dl})$, bilirubin $(4.87 \mathrm{~g} / \mathrm{dl}), \operatorname{AST}(29.93 \mathrm{u} / \mathrm{l}), \operatorname{ALT}(28.90 \mathrm{u} / \mathrm{l})$, and ALP (115.65 $\mathrm{u} / \mathrm{l})$ as compared to those in the untreated animals. Furthermore, histopathological examination showed that the oral administration of fruit pulp ethanol extract exhibited no pathological abnormality on rat liver tissue (Iheagwam et al., 2017). Ukwubile et al. (2017) therefore concluded that $T$. daniellii may contain metabolites that are capable of ameliorating or protecting against liver injury.

According to Olorunnisola et al. (2017), the $\mathrm{LD}_{50}$ value of ethanol leaf extract was reported to be greater than $5000 \mathrm{mg} / \mathrm{kg}$ in male Wistar rats. In the same study, the nephroprotective effect of ethanol leaf extract of T. daniellii on streptozotocin-induced diabetic rats was evaluated. Oral administration of 250 and $500 \mathrm{mg} / \mathrm{kg}$ of the extract dose-dependently ameliorated deranged electrolyte balance and compared favorably with the effect of glibenclamide (Olorunnisola et al., 2017). Lethality assessment of the hexane, aqueous acetone, and ethanol leaf extract $(20,40,60,80$, and $100 \mu \mathrm{g} / \mathrm{ml})$ against larvae of brine shrimp naupli revealed that the aqueous and ethanol extracts of the leaf were nontoxic with $\mathrm{LD}_{50}$ values of 592.95 and $281.12 \mu \mathrm{g} / \mathrm{ml}$, respectively. However, acetone and hexane extracts showed significant toxicities ( $\mathrm{LC}_{50}$ of $31.27 \mu \mathrm{g} / \mathrm{ml}$ and $22.77 \mu \mathrm{g} / \mathrm{ml}$, respectively). The discrepancies in toxicity of the extracts are suggestive of the presence of cytotoxic and harmful com- 
pounds, which might be attributed to the extraction solvents (Adeogun et al., 2016).

\section{Hypolipidemic activities of T. daniellii}

Hypolipidemic activities of ethanol leaf extracts of T. daniellii (500-1500 mg/kg) were evaluated by Shalom et al. (2018). The study revealed that a 2 -week administration of the extracts had a positive effect on the lipid profile of the plasma, kidney, and liver. A significantly lower cholesterol concentration was observed in the plasma of animals treated with $1500 \mathrm{mg} / \mathrm{kg}$ extract. Plasma low-density lipoprotein (LDL) level was also considerably reduced to $0.53,0.47$, and $0.48 \mathrm{mmol} / 1$ for all extract concentrations $(500,1000$, and $1500 \mathrm{mg} / \mathrm{kg}$, respectively) as compared to control $(0.62 \mathrm{mmol} / \mathrm{l})$. A significantly increased high-density lipoprotein (HDL) concentration was observed in the lipid analysis of the plasma $(1.64 \mathrm{mmol} / \mathrm{l})$, liver $(0.18 \mathrm{mmol} / \mathrm{l})$, and kidney $(0.05 \mathrm{mmol} / \mathrm{l})$ of $1000 \mathrm{mg} / \mathrm{kg}$ extract-treated animals and were respectively comparable to $1.12,0.12$, and $0.05 \mathrm{mmol} / \mathrm{l}$ observed for the vitamin C-treated group.

Juxtaposing the serum lipid analysis of the aqueous leaf extract-treated rats with streptozotocin-induced untreated diabetic rats, it was observed that in the $100 \mathrm{mg} / \mathrm{kg}$ extract-fed group, serum cholesterol $(72.66 \mathrm{mg} / \mathrm{dl})$ and triglycerides $(265.02 \mathrm{mg} / \mathrm{dl})$ levels were significantly reduced compared to 120.25 and $386.66 \mathrm{mg} / \mathrm{dl}$, respectively, noted in untreated diabetic rats (Adedosu et al., 2017). In addition, serum HDL values of 30.90 and $19.00 \mathrm{mg} / \mathrm{dl}$ were recorded for extract-treated and untreated diabetic rats, respectively (Adedosu et al., 2017). Osuaocha et al. (2018) reported that ethanol and aqueous leaf extracts $(200 \mathrm{mg} / \mathrm{kg})$ exhibited no adverse effect on the lipid profile of rats. The measured values were not significantly different from those of control animals treated with distilled water. As mentioned by Omisope et al. (2016), the essential oil extract of leaf conferred adaptogenic ability and capacity to tolerate nonspecific stress and restored or maintained normal lipid homeostasis in stress-induced hyperlipidemic rats. It was concluded that the extract reduced serum LDL concentration from 28 to $15 \mathrm{mg} / \mathrm{dl}$ and concomitantly increased HDL level from 13 to $25 \mathrm{mg} / \mathrm{dl}$.

\section{Antimicrobial activities of T. daniellii}

Recently, there has been a worldwide drive and resurgence to develop antimicrobial agents from natural sources, which would serve as an alternative to the presently available synthetic drugs. Residues of synthetic antibiotics have been reported as a source of pollutants in animal feeds and in aquatic and terrestrial ecosystems (Kim and Aga, 2007; Kraemer et al., 2019). Several cases of antimicrobial drug resistance due to prolonged and indiscriminate use of antibiotics have been reported in the literature (Manaia, 2017; Zhou et al., 2018b). Many studies have reported various levels of efficacy of medicinal plants (Fadahunsi et al., 2017; Fadahunsi and Adeyina, 2019; Badmus et al., 2019 Olasehinde et al., 2019; Adegbola et al., 2020). Different solvent extracts and fractions of $T$. daniellii have been evaluated against various species of microorganisms, and the obtained results indicated that the plant might be a good candidate for the development of antimicrobial agents from natural origin. By using the disc diffusion method, Adeogun et al. (2016) evaluated the antifungal properties of acetone, ethanol, hexane and aqueous extracts of $T$. $d a-$ niellii at the concentrations of 0.1-10 g against isolated fungi (Aspergillus aculeatus, Aspergillus niger, Aspergillus flavus strain, Rhizopus stolonifer, Issatchenkia orientalis, Meyerozyma guilliermondii, Fusarium oxysporum, Paecilomyces variotii, Penicillium crustosum, Trichoderma harzianum, and Meyerozyma caribbica) from orange juice and corn jell-O (Eko). It was observed that the ethanol extract showed the most potent activity against the tested isolates. Moreover, the ethanol and acetone extracts exhibited the lowest minimum inhibitory concentration (MIC), highest fungicidal, and zone of inhibition activities in a dose-dependent manner. In contrast, the aqueous and hexane extracts were quite ineffective. In the study of Adebayo and Kolawole (2010), the broth dilution method showed the sensitivity of spoilage fungi (Saccharomyces cerevisiae, S. chevalieri, Rhizopus, Mucor, Penicillium, Aspergillus niger, and Aspergillus flavus) isolated from Eba, an indigenous staple food in Nigeria, and white bread to aqueous and methanol leaf extract of T. daniellii. It was noted that the methanol extract of $T$. daniellii had greater activity against the tested organisms than the aqueous extract.

By using the agar well diffusion method, the antibacterial activity of ethanol leaf extract $(1.25-20 \mathrm{mg} / \mathrm{ml})$ of the plant was investigated against gram-positive Staphylococcus aureus ATCC 29213, Bacillus subtilis ATCC 12432, and Streptococcus pyogenes ATCC 8668 and gram-negative Shigella dysenteriae (clinical isolate), 
Campylobacter jejuni (clinical isolate), and Salmonella typhi ATCC23564. The antibacterial activity exhibited by the extract was considerable and comparable to that of ciprofloxacin (Ukwubile et al., 2017). Interestingly, chloroform, methanol, ethanol, and aqueous leaf extracts exhibited no activity against the selected strains of food spoilage microorganisms ( Salmonella typhimurium, Shigella dysenteriae, Shigella sp., Escherichia coli, Staphylococcus aureus, Streptococcus lactis, Leuconostoc sp., Pediococcus cerevisiae, Bacillus cereus, Candida krusei, Candida albicans, Aspergillus niger, Aspergillus flavus, and Trichoderma konigii) (Adegunloye et al., 2006; Ojekale et al., 2007).

\section{Antidiabetic and antihyperglycemic activities of T. daniellii}

Medicinal herbs have been popularly used for managing glucose-related metabolic disorders in many developing nations. This might be due to continued ancestral practices, beliefs, and dispositions; ubiquitous nature of these plants; financial constraints due to low income; and unwanted side effects of prolonged use of allopathic and conventional diabetic medications (Sofowora, 1993; Kubukeli, 1999; WHO, 2002; Parmer, 2005; Tabut, 2006; Anoka, 2012; Das and Barman, 2012; Priscilla, 2013). According to Trinter (2007), Africans have developed their own effective ways of treating diseases long before the arrival of conventional medicine. Different ethnobotanical surveys have reported the use of T. daniellii plant parts as a recipe in the formulation of traditional and folkloric antidiabetic agents (Coolborn and Adegbemisipo, 2008; Borokini et al., 2013). Some researchers have also reported different glucose lowering abilities and mechanisms of action of the plant. According to Elemo et al. (2000), three glycoproteins (P1, P2, and S) isolated and purified from $T$. daniellii seed and pulp crude extracts conferred considerable inhibitory activity against $\alpha$-amylase. The highest inhibitory activity (57\%) observed was demonstrated by glycoprotein of the seed with optimum temperature and $\mathrm{pH}$ of $30^{\circ} \mathrm{C}$ and 6.5 , respectively.

Antihyperglycemic activities of methanol and ethanol leaf extracts of $T$. danielliii in streptozotocin-induced diabetic rats have been reported (Chikezie et al., 2015; Ogoloma et al., 2017). Adedosu et al. (2017) reported that fasting blood sugar (FBS) of extract-fed diabetic rats $(145 \mathrm{mg} / \mathrm{dl})$ was significantly lower than that of the un- treated diabetic rats $(450 \mathrm{mg} / \mathrm{dl})$ after 15 days of treatment. To clarify the likely mechanisms of action, Olorunnisola et al. (2019) evaluated the in vitro antidiabetic activity of ethanol leaf extract of $T$. daniellii. It was observed that the ethanol leaf extracts $(250,500$, and $750 \mu \mathrm{g} / \mathrm{ml}$ ) induced a dose-dependent $\alpha$-amylase inhibition (38.41, 46.31, and 50.81\%, respectively). An increased glucose uptake in yeast cells was also observed after $72 \mathrm{~h}$, which was better than the standard drug metronidazole. Simultaneously, $T$. daniellii showed better (87.51\%) ability to inhibit hemoglobin glycosylation than standard drug (82.10\%) (trolox). In the same study, in vivo glucose lowering activity showed that the administration of the extract at 250 and $500 \mathrm{mg} / \mathrm{kg}$ body weight resulted in a significant $(P<0.05)$ dose-dependent decrease in the blood glucose as compared to the diabetic control group. In addition, Emudainohwo et al. (2015) reported that acute and sub-acute treatments with ethanol leaf extract (200 and $400 \mathrm{mg} / \mathrm{kg}$ ) caused a significant reduction in fasting blood glucose value and glycosylated hemoglobin (HbA1) and an observable increase in serum amylase of diabetic animals.

\section{Effect of T. daniellii extracts on hematological parameters}

Investigation on the effect of methanol leaf and rhizome extracts on hematological parameters showed a reduction in red blood cell and white blood cell count. Animals with low white blood cells are highly susceptible to develop infection and are incapable of generating antibodies for disease resistance (Soetan et al., 2013). However, no significant effect $(P<0.05)$ on hemoglobin, hematocrit, and platelet concentrations within the 28-day study period was observed. It was also noted that both extracts caused a significant increase $(P<0.05)$ in the value of mean corpuscular hemoglobin concentration (MCHC) (Ogoloma et al., 2017). Adedosu et al. (2017) also reported a significant decrease in the counts of white blood cells $\left(5.38 \times 10^{9} / 1\right)$, lymphocytes $(2.24$ $\left.\times 10^{9} / 1\right)$, and platelets $\left(432 \times 10^{9} / 1\right)$ coupled with a significant $(P<0.05)$ increase in total serum proteins $(9.5 \mathrm{mg} / \mathrm{dl})$ and red blood cells $\left(7.95 \times 10^{12} / \mathrm{l}\right)$ in diabetic rats treated with ethanol leaf extract for 15 days. Another study conducted by Ogbonnaya et al. (2019) evaluated hematological indices of Wistar rats administered with aqueous and methanol leaf extracts of $T$. daniellii. There was a significant decrease in the hemoglobin con- 
centration $(13.70 \mathrm{~g} / \mathrm{l})$, red blood cells $\left(62.20 \times 10^{6} / \mu \mathrm{l}\right)$, and packed cell volume $(38.75 \%)$ in the group administered with $200 \mathrm{mg} / \mathrm{kg}$ methanol extract of $T$. danielliias compared to the group administered with distilled water alone. However, there was no significant difference in the values obtained for rats administered with $200 \mathrm{mg} / \mathrm{kg}$ aqueous leaf extract of $T$. daniellii and distilled water alone. Thus, the authors concluded that the extracts had no significant effect on hematological indices.

\section{Effect of T. daniellii on weight of treated rats}

The effects of a 14-day oral dose of ethanol seed extracts $(500,1000$, and $1500 \mathrm{mg} / \mathrm{kg})$ on total body and organ weight were investigated and compared with the effects on ascorbic acid-treated rats (Shalom et al., 2017). There was no significant change in organ weights, but an observable reduction (16.33 g) in total body weight of the extract-treated animals was noted compared to the control animals $(27.33 \mathrm{~g})$. This might be due to the high crude fiber and low fat content of the seeds (Lim, 2012; Abiodun et al., 2014). Emudainohwo et al. (2015), however, reported a significant (7.76\%) increase in the weight of diabetic rats treated with ethanol leaf extract of $T$. daniellii. Corroboratively, Nwonuma et al. (2016) reported a $1.70 \%$ weight increase in potassium bromate-exposed rats treated with ethanol leaf extract of $T$. daniellii.

\section{Phytoremediative activity of T. daniellii}

The use of plants in remediation and cleaning of petroleum-contaminated soils is cheap and very effective (Singh and Kumar, 2018). Plants such as Vicia faba and Zea mays have been documented to thrive and grow on soils polluted with hydrocarbons (Quinones-aquilar et al., 2003). Therefore, the ability of $T$. daniellii to grow on crude oil and acid-polluted soil was evaluated as a measure of its bioremediative capability and potential (Ekpo et al., 2012). In a 4-week study, different concentrations $(0.5-17.5 \mathrm{ml})$ of crude oil were applied to the soil on which $T$. daniellii was grown. It was observed that morphological parameters such as mean chlorophyll content (2.51), leaf area (276.40), and number of leaves (4.7) of $T$. daniellii grown on crude oil were statistically nonsignificant from the control. Nonetheless, physiological parameters such as sulfate ion (0.3), aluminum oxide (0.3), hydrogen ion (0.4), and dry matter (91.6) contents were significantly different (Ekpo et al., 2012).

\section{Insecticidal activity of T. daniellii}

Ojekale et al. (2007) reported the insecticidal potential of the essential oil of $T$. daniellii leaves against Sitophilus zeamais. A lethal concentration of $345.2 \mathrm{mg}$ per $100 \mathrm{ml}$ after $72 \mathrm{~h}$ was reported. However, this observed activity was significantly inferior than those of standard insecticides (permethrin and allethrin).

\section{Conclusions}

Investigations of $T$. daniellii by various scientific studies revealed that the plant possesses far-reaching nutrients and medicinally important phytoconstituents. It can be deduced that the seeds have better nutritional values and importance. However, the methanol, acetone, and hexane extracts of the rhizome and leaves were observed to be toxic, and caution should be taken when consuming them. Conclusively, the aqueous and ethanol extracts of the seed and leaf were regarded as safe, while the ethanol leaf extract was found to be the most potent of the extracts of all morphological organs. Thus, it should be considered and used for its pharmaceutical potential.

\section{References}

Abbiw D.K. (1990) The useful plants of Ghana: West African uses of wild and cultivated plants. Intermediate Technology Publications/Royal Botanic Gardens, Kew, London.

Abiodun O.A., Akinoso R., Olosunde O.O., Adegbite J.A., Omolola O.A. (2014) Nutritional quality and essential oil compositions of Thaumatococcus daniellii (Benn.) tissue and seed. Food Chem. 160: 286-291.

Adebayo G.J., Kolawole L.A. (2010) In vitro activity of Thaumatococcus daniellii and Megaphrynium macrostachyum against spoilage fungi of white bread and 'Eba', an indigenous staple food in Southern Nigeria. Afr. J. Microbiol. Res. 4(11): 1076-1081.

Adedosu O.T., Badmus J.A., Adeleke G.O., Olalere (2017) Thaumatococcus daniellii extract modulates glibenclamide activity and ameliorates heamatological disorders, oxidative stress and dyslipidemia associated with diabetes mellitus in rats. Brit. J. Pharm. Res. 16(5): 1-12.

Adegbola P.I., Adetutu A., Olaniyi T.D. (2020) Antioxidant activity of Amaranthus species from the Amaranthaceae family: a review. South Afr. J. Bot. 133: 111-117.

Adegunloye D.V., Aggary O.O., Adebolu T.T., Adetuyi F.C. (2006) Effect of leaf-packaging on the microbiological assessment of some food items. Afr. J. Biotech. 5(5): 445-447.

Adeogun O., Adekunle A., Ashafa A. (2016) Chemical composition, lethality and antifungal activities of the extracts 
of leaf of Thaumatococcus daniellii against foodborne fungi. Beni-Suef Univ. J. Basic Appl. Sci. 5: 356-368.

Adeogun O.A., Adekunle A.A., Adongbede E.M. (2017) Effect of leaf extract of selected plants on quality of stored sinensis (sweet orange) juice. Not Sci. Biol. 9(2): 256-262.

Adesina S.K., Higginbotham J.D. (1977) Studies on a novel polysaccharide gel from the fruit of Thaumatococcus danielli (Benth). Carbohyrirote Res. 59: 517-524.

Adeyemi T.O.A., Idowu O.D., Ogboru R.O., Iyebor W.E., Owoeye E.A. (2014) Phytochemical screening, nutritional and medicinal benefits of Thaumatococcus daniellii Benn (Benth.). Int. J. Appl. Res. Technol. 3(8): 92-97.

Ahmed M., Qin P., Gu Z., Liu Y., Sikandar A., Hussain D., Javeed A., Jamil S., Mazher F., Ran A., Hongxia G., Ying D., Weijing W., Yumeng Z., Mingshan J. (2020) Insecticidal activity and biochemical composition of Citrullus colocynthis, Cannabis indica and Artemisia argyi extracts against cabbage aphid (Brevicoryne brassicae L.). Sci. Rep. 10: $522-528$.

Ali S.M.H., Muhammad A.M., Faisal H., Muhammad F., Dilbar H., Muhammad S., Abdul G. (2004) Insecticidal activity of turmeric (Curcuma longa) and garlic (Allium sativum) extracts against red flour beetle, Tribolium castaneum: a safe alternative to insecticides in stored commodities. J. Entomol. Zool. Stud. 3: 201-205.

Annapurna A., Reddy C.S., Akondi R.B., Rao S.R. (2009) Cardioprotectiveactions of two bio flavonoids, quercetin and rutin, in experimental myocardial infarction in both normal and streptozotocin-induced type I diabetic rats. J. Pharm. Pharmacol. 61: 1365-1374.

Anoka A.N. (2012) Herbal medicine used in the treatment of malaria: Vernonia amygdalina: an overview of evidence and pharmacology. [in:] Toxicity and drug testing. Ed. Acree B. Croatia. InTech.

Arowosoge O.G.E., Popoola L. (2006) Economic analysis of Thaumatococcus daniellii (Benn.) Benth. (Miraculous berry) in Ekiti State, Nigeria. J. Food Agric. Env. 4(1): 264-269.

Badmus J.A., Ekpo O.E., Hussein A.A., Meyer M., Hiss C. (2019) Cytotoxic and cell cycle arrest properties of two steroidal alkaloids isolated from Holarrhena floribunda (G. Don) T. Durand \& Schinz leaves. BMC Compl. Alternat. Med. 19(112): 1-9.

Bhattacharya S. (2015) Reactive oxygen species and cellular defense system. [in:] Free radicals in human health and diseases. Ed. Rani V., Yadav U.C.S. Springer India: 17-29.

Boadi S., Acheamfour M.B., Appiah F.U., Jamro G.M. (2014) Non-timber forest product yield and income from Thaumatococcus daniellii under a mixed tree plantation system in Ghana. Int. J. Forest. Res. doi.org/10.1155/2014/52486

Boadi W.Y., Amartey P.K., Andrew L. (2016) Effect of quercetin, genistein and kaempferol on glutathione and gluta thione-redox cycle enzymes in 3T3-L1 preadipocytes. Drug Chem. Toxicol. 39(3): 239-247.

Boots A.W., Haenen G.R., Bast A. (2008) Health effects of quercetin: from antioxidant to nutraceutical. Eur. J. Pharmacol. 585: 325-337.
Borokini T.I., Ighere D.A., Clement M., Ajiboye T.O., Alowonle A.A. (2013) Ethnobiological survey of traditional medicine practice for the treatment of piles and diabetes mellitus in Oyo State. J. Med. Plants Stud. 1(5): 30-40.

Chahar M.K., Sharma N., Dobhal M.P., Joshi Y.C. (2011) Flavonoids: a versatile source of anticancer drugs. Pharmacogn. Rev. 5: 1-12.

Chiech D.C.J. (2008) Thaumatin recovery via bioengineering route and in-vitro culture of Thaumatococcus daniellii. Thesis submitted in fulfillment of the requirements for the degree of Doctor of Philosophy. Universiti Sains, Penang, Malaysia.

Chikezie P.C., Ibegbulem C.O., Mbagwu F.N (2015) Medicinal potentials and toxicity concerns of bioactive principles. Med. Aromat. Plants 4: 202.

Choudhari A.S., Mandave P.C., Deshpande M., Ranjekar P., Prakash O. (2020) Phytochemicals in cancer treatment: from preclinical studies to clinical practice. Front. Pharmacol. 10: 1614.

Chu Y., Sun J., Wu X., Liu R.H. (2002) Antioxidant and antiproliferative activity of common vegetables. J. Agric. Food Chem. 2002(50): 6910-6916.

Coolborn A.F., Adegbemisipo A.A. (2008) Medicinal vegetal use by traditional healers in Ekiti State of Nigeria for diabetes treatment. Int. J. Pharm. Res. Technol. 8: 21-28.

Corson T.W., Crews C.M. (2007) Molecular understanding and modern application of traditionalmedicines: triumphs and trials. Cell 130(5): 769-774.

Cusack M., Stephen A.G., Powls R., Beynon R.J. (1991) Purification and characterization of thaumatopain. a cysteine protease from the arils of Thaumatococcus danielli. Biochem. J. 274: 231-236.

Das S., Barman S. (2012) Antidiabetic and antihyperlipidemic effects of ethanolic extract of leaves of Punica granatum in Alloxan-induced Non-insulin-dependent diabetes mellitus albino rats. Indian J. Pharmacol. 44: 219-224.

Dorman H.J., Deans S.G. (2000) Antimicrobial agents from plants: antibacterial activity of plant volatile oils. J. Appl. Microbiol. 88: 308-316.

Ekpo I.A., Agbor R.B., Okpako E.C., Osuagwu B.E., Otu P.A. (2012) Effect of crude oil and simulated acid rain on the growth and physiology of Thaumatococcus daniellii. J. Bio. Env. Sci. 2(9): 21-25.

Elemo B.O., Adu O.B., Ogunrinola O.O., Efuwape T.O., Olaleye K.O., Kareem A.A. (2011) Biological evaluation of Thaumatococcus danielli waste protein. Pakistan J. Nutr. 10(11): 1048-1054.

Elemo B.O., Elemo G.N., Agboola O.O., Oyedun A.B. (2001) Studies on some antinutritve factors and invitro protein digestibility of $T$. daniellii (benth) waste. Nigerian J. Biochem. Mol. Biol. 6: 43-46.

Elemo B.O., Ogolo O., Adeyemi O., Elemo G.N. (2000) Alpha Amylase inhibitor from $T$. daniellii (Benth). Nigerian J. Biochem. Mol. Biol.15: 161-165.

Elemo B.O., Oladimeji O.S., Adu O.B., Olaleye O.I. (1999) Chemical evaluation of waste from Thaumatococcus da- 
nielli (Benth) processing. Plant Foods Human Nutr. 54: 101-108.

Emudainohwo J.O.T., Erhirhie E.O., Moke E.G., Ejebe D.E. (2015) Hypoglycemic Effect of ethanol leaf extract of Thaumatococcus danielli in Alloxan Induced Diabetic Wistar Rats. 10SR. J. Pharm. Biol. Sci. 10(2): 59-64.

Essien E.I., Akaninyene A.D., Etuk S.E., Peter G.I., Udofia A.E. (2016) Investigation of thermal properties of plantain (Musa paradisiaca) and Mfang Aya (Thaumatococcus daniellii) as thermal radiation insulator. J. Nat. Sci. Res. 6(15): 33-37.

Fadahunsi I.F., Adeyina O.E. (2019) Antimicrobial susceptibility of spoilage bacteria of water melon juice to ethanol extract of roselle (Hibiscus sabdariffa) calyces and their survival in the extract fortified water melon juice. EC Microbiology 15(10): 1140-1153.

Fadahunsi O.S., Olorunnisola O.S., Owoade O. (2017) In-vitro anti-inflammatory activities of the leaves extracts of Sphenocentrum jollyanum Pierre. J. Appl. Life Sci. Int. 18(4): 1-9.

Falodun A. (2010) Herbal medicine in Africa-distribution, standardization and prospects. Res.J.Phytochem.4(3): 154-161.

Fang J.Y., Tsai T.H., Lin Y.Y., Wong W.W., Wang M.N., Huang J.F. (2007) Transdermal deliveryof tea catechins and theophylline enhanced by terpenes: a mechanistic study. Biol. Pharm. Bull. 30: 343-349.

Fang M.Z., Wang Y., Ai N., Hou Z., Sun Y., Lu H. (2003) Tea polyphenol; epigallocatechin-3-gallate inhibits DNA methyltransferase and reactivates methylation-silenced genes in cancer cell lines. Cancer Res. 63: 7563-7570.

Fosso M.Y., Chan K.Y., Gregory R., Chang W.T. (2012) Library synthesis and antibacterial investigation of cationic anthraquinone analogs. ACS Comb Sci. 14(3): 231-235.

Franke W. (1989) Crop science. Georg Thieme Verlag, Stuttgart New York: 231-232.

Gabas-Rivera C., Barranquero C., Martínez-Beamonte R., Navarro M.A., Surra J.C., Osada J. (2014) Dietary squalene increases high density lipoprotein-cholesterol and paraoxonase 1 and decreases oxidative stress in mice. PLoS ONE 2(9): e104224.

Gan K.H., Teng C.H., Lin HC., Chen KT., Chen YC., Hsu MF., Wang JP., Teng CM., Lin CN. (2008) Antiplatelet effect and selective binding to cyclooxygenase by molecular docking analysis of 3-alkylaminopropoxy-9,10-anthraquinone derivatives. Biol. Pharm. Bull. 31: 1547-1551.

Gloria M.B.A. (2003) Encyclopedia of food sciences and nutrition. Elsevier Science ltd.: 5695-5702.

Gourhan A.L. (1975) The flowers found with Shanidar IV, a Neanderthal burial in Iraq. Science 190: 562-564.

Gulpinar A.R., Orhan I.E., Kan A., Senol F.S., Celik S.A., Kartal M. (2012) Estimation of in vitro neuro protective properties and quantification of rutin and fattyacids in buckwheat (Fagopyrum esculentum Moench) cultivated in Turkey. FoodRes. Int. 46: 536-543.

Gyamfi M.A., Aniya Y. (2002) Antioxidant properties of Thonningianin $A$, isolated from the African medicinal herb, Thonningia sanguine. Biochem. Pharmacol. 63: 1725-1737.
Hamalaina M., Nieminen R., Vuorela P., Heinonen M., Moilanen E. (2007) Anti-inflammatory effects of flavonoids: genistein, kaempferol, quercetin, and daidzein inhibit STAT-1 and $N F-\kappa B$ activations, whereas flavone, isorhamnetin, naringenin, and pelargonidin inhibit only $N F \kappa B$ activation along with their inhibitory effect on iNOS expression and NO production in activated macrophages. Mediators Inflam. Article ID 45673. doi: 10.1155/2007/45673

Hamid A.A., Aliyu M.A., Abubakar L.Z., Mukadam A.A., Shehu A., Egharevba G., Adisa M.J., Ajibade S.O., Zubair A.O., Fagbohun E.O. (2017) Thaumatococcus daniellii leaves: its chemical compositions, antioxidant and antimicrobial activities. Ife J. Sci. 19(2): 409-416.

Hao H.H., Shao Z.M., Tang D.Q., Lu Q., Chen X., Yin X.X., Wu J., Chen H. (2012) Preventive effects of rutin on the development of experimental diabetic nephropathy in rats. Life Sci. 91: 959-967.

Hikal W.M., Baeshen R.S., Said-Al H.A. (2017) Botanical insecticide as simple extractives for pest control. Cogent Biol. 3(1): 1404-1274.

Ho H.J., Shirakawa H., Yoshida R., Ito A., Maeda M., Goto T., Komai M. (2016) Geranylgeraniol enhances testosterone production via the $c A M P /$ protein kinase $A$ pathway in testis-derived I-10 tumor cells. Biosci. Biotech. Biochem. 80(4): 791-797.

Howida S.A.F. (2016) Physiological changes due to hepatotoxicity and the protective role of some medicinal plants. Beni-Suef Univ. J. Basic Appl. Sci. 5: 134-146.

Huang M., Lu J.J., Huang M.Q., Bao J.L., Chen X.P., Wang Y.T (2012) Terpenoids: natural products for cancer therapy. Expert Opin Investig. Drugs. 21: 1801-1818.

Huang Q., Lu G., Shen HM., Chung MC., Choon N.O. (2007) Anti-cancer properties of anthraquinones from rhubarb. Med. Res. Rev. 27(5): 609-630.

Huang W.Y., Liu Y.M., Wang J., Wang X.N., Li C.Y. (2014) Anti-inflammatory effect of the blueberry anthocyanins malvidin-3-glucoside and malvidin-3-galactoside in endothelial cells. Molecules 19: 12827-12841.

Hussain T., Gupta S., Adhami V.M., Mukhtar H (2005) Green tea constituent epigallocatechin-3-gallate selectively inhibits COX-2 without affecting COX-1 expression in human prostate carcinoma cells. Int. J. Cancer 113: 660-669.

Hutchinson J., Dalziel J.M. (1963) Flora of West Tropical African. Ed. Hepper F.N. Crown Agents for Oversea Governments and Administrations. London, United Kingdom: 79-89.

Iheagwam F.I., Shalom N., Chinedu S.N., Emiloju O.C., Okenmuo A.C. (2017) Fruit extract of Thaumatococcus danielli reduces oxidative stress in rats. FASEB J. 31(1): 779-785.

Jackson T.C., Verrier J.D., Kochanek PM (2013) Anthraquinone-2-sulfonic acid (AQ2S) is a novel neurotherapeutic agent. Cell Death Dis. 4(1): e451.

Jennings S.B., Brown N.D., Boshier D.H., Whitmore T.C., Lopes J.A. (2001) Ecology provides a pragmatic solution to the maintenance of genetic diversity in sustainably managed tropical rainforest. Forest Ecol. Manag. 154(1-2): 1-10. 
Khan N., Karodi R., Siddiqui A., Thube S., Rub R. (2011) Development of anti-acne gel formulation of anthraquinones rich fraction from Rubia cordifolia (Rubiaceae). Int. J. Appl. Res. Nat. Prod. 4(4): 28-36.

Kim S., Aga D.S. (2007) Potential ecological and human health impacts of antibiotics and antibiotic-resistant bacteria from wastewater treatment plants. J. Toxicol. Environ. Health B Crit. Rev. 10(8): 559-573.

Kozlowska B.T., Dworacka M., Kuczynski S., Abramczyk M., Kolanos R.., Wysocka W., Lopez P.M, Winiarska H. (2007) Hypoglycaemic effect of quinolizidine alkaloids-lupanine and 2-thionosparteine on non-diabetic and streptozotocin-induced diabetic rats. Eur. J. Pharmacol. 565(1-3): 240-244.

Kraemer A.S., Ramachandran A., Perron G.G. (2019) Antibiotic pollution in the environment: from microbial ecology to public policy. Microorganisms 7: 1-24.

Kubukeli P.S. (1999) Traditional healing practice using medicinal herbs. Lancet 354 (Suppl. 4): 24.

Kumar R.S., Yamauchi I., Narayan B., Katsuki A., Hosokawa M., Miyashita K (2016) Squalene modulates fatty acid metabolism: enhanced EPA/DHA in obese/diabetic mice (KK-Ay) model. Eur. J. Lipid Sci. Technol. 118: 1935-1941.

Lee J.S., Kim Y.R., Park J.M., Kim Y.E., Baek N.I., Hong E.K. (2015) Cyanidin-3-glucoside isolated from mulberry fruits protects pancreatic b-cells against glucotoxicity-induced apoptosis. Mol. Med. Rep. 11: 2723-2728.

Leung W.C., Lin C.J., Hour M.J., Yang W.H., Wang M.Y., Lee H.Z. (2007) Kaempferol induces apoptosis in human lung non-small carcinoma cells accompanied by an induction of antioxidant enzymes. Food Chem. Toxicol. 45: 2005-2013.

Li X.J., Zhang H.Y. (2008) Western-medicine-validated antitumor agents and traditional Chinese medicine. Trends Mol. Med. 14(1): 1-2.

Lim T.K. (2012) Edible medicinal and non-medicinal plants fruits. Springer Sci. Business Media 3: 34-38.

Lin J., Cheng Y., Wang T., Tang L., Sun Y., Lu X., Yu H. (2016) Soya saponin Ab inhibits lipopolysaccharide-induced acute lung injury in mice. Int. Immunopharmacol. 30: 121-128.

Lobo V., Patil A., Phatak A., Chandra N. (2010) Free radicals, antioxidants and functional foods: impact on human health. Pharmacogn Rev. 4(8): 118-126.

Lorenzo C., Eugenio A. (2011) Use of terpenoids as natural flavouring compounds in food industry. Recent Patents Food Nutr. Agric. 3: 9-16.

Maggi L., Carmona M, del Campo C.P., Kanakis C.D., Anastasaki E., Tarantilis P.A. (2009) Worldwide market screening of saffron volatile composition. J. Sci. Food Agric. 89: 1950-1954.

Makinde S.C.O., Taiwo C.K. (2004) In situ population evaluation of Thaumatococcus danielli (Benth). ASSET Int. J. 3(1): $75-80$.

Manaia C.C. (2017) Assessing the risk of antibiotic resistance transmission from the environment to humans: non-direct proportionality between abundance and risk. Trends Microbiol. 25(3): 173-181.
Mansfeld R. (1986) Verzeichnis landwirtschaftlicher und gärtnerischer Kulturpflanzen. Springer, Berlin: 1690-1691.

Mastubara T., Takakura N., Urata M., Muramatsu Y., Tsuboi M., Yasuda K., Addison W.N., Zhang M., Matsuo K., Nakatomi C., Shigeyama-tada Y., Kaneuji T., Nakamichi A., Kokabu S. (2018) Geranylgeraniol induces PPAR expression and enhances the biological effects of a PPAR, agonist in adipocyte lineage cells. In vivo 32: 1339-1344.

Matsuura M. (2001) Saponins in garlic as modifiers of the risk of cardiovascular disease. J. Nutr. 131: 1000-1005.

Most B.H., Summerfield R.J., Boxall M. (1978) Tropical plants with sweetening properties, 2. Thaumatococcus daniellii. Econ. Bot. 32: 321-335.

Motawi T.M., Sadik N.A., Refaat A. (2010) Cytoprotective effects of DL-alpha-lipoic acid or squalene on cyclophosphamide-induced oxidative injury: an experimental study on rat myocardium, testicles and urinary bladder. Food Chem. Toxicol. 48: 2326-2336.

Mumoli N., Cei M., Cosimi A. (2006) A drug-related hepatotoxicity. N. Engl. J. Med. 354(20): 2191-2193.

Murakami C., Hirakawa Y., Inui H., Nakano Y., Yoshida H. (2002) Effect of tea catechins on cellular lipid peroxidation and cytotoxicity in HepG2 cells. Biosci. Biotechnol. Biochem. 66: 1559-1562.

Ndukwe A.A., Enoh E.A., Aniere Q.U. (2014) Determination of morphological and nutritional properties of Thaumatococcus daniellii and effect of harvesting method on the plant growth international. J. Innov. Sci. Res. 11(2): 304-311.

Noonan S.C., Savage G.P. (1999) Oxalate content of foods and its effect on humans. Asian Pac. J. Clin. Nutr. 8: 64-74.

Nwonuma C.O., Irokanulo E.O., Iji C.E., Alejolowo O.O., Adetunji C.O. (2016) Effect of Thaumatococcus daniellii leaf rat-feed on potassium bromate induced testicular toxicity. Asian Pacific J. Reprod. 5(6): 500-505.

Oboh G., Akinyemi A.J., Oyeleye I.S., Williamsnelson K. (2016) Protective effect of phenolic extracts from two species of miracle berry leaves (Thaumatococcus daniellii and Megaphrynium macrostachyum) on some pro-oxidant induced oxidative stress in rat pancreas in vitro. J. Appl. Pharm. Sci. 6(1): 118-124.

Odoh R., Yebpella G.G., Udegbunam I.S., Christopher S.A. (2018) Nutritional evaluation and proximate analysis of varieties of some edible leafy vegetables in Northern Nigeria. J. Biosci. Biotech. Discov. 2: 30-45.

Oforibika G.A., Ogoloma J.U., Tamunodiepriye E. (2017) Potential of Thaumatococcus danielli in animal nutrition. Nature Sci. 15(10): 97-100.

Ogbonnaya E., Kalu A.A., Wusa M., Sunday E.A., Chinedu E.D., Collins N. (2019) Hematological evaluation of aqueous and methanolic leaf extracts of Thaumatococcus daniellii and Alchornea cordifolia in Wistar rats. GSC Biol. Pharm. Sci. 8(1): 123-127.

Ogoloma U.J., Wegu M., Abbey B.N. (2017) Hematological effects of methanolic root and leaf extracts of Thaumatococcus danielli in Wistar rat. Biomed. Nursing 3(3): 42-54. 
Ojekale A.B., Makinde S.C.O., Osileye O.(2007) Phytochemistry and anti-microbial evaluation of Thaumatococcus danielli, Benn. (Benth.) leaves. Nigerian J. Sci. 25(2): 176-183.

Ojekale A.O., Oladipupo A., Lawal O.S., Adeola A., Segun F.O., Samuel O., Ismaila A.I., Opoku A.R. (2013) Volatile constituents, antioxidant and insecticidal activities of essential oil from the leaves of Thaumatococcus danielli (Benn.) Benth. from Nigeria. Iosr J. Pharm. 3: 1-5.

Ojo A., Enujiugha V.N., Ayo-Omogie H.N., Abiodun O.A.J. (2017) Comparative study on the effect of Thaumatococcus daniellii (Benn) Benth sweetener on the physicochemical and sensory properties of sorghum based Kununzaki drink. Appl. Sci. Environ. Manage. 21(6): 1073-1078.

Okafor I.J., Nweke E.O., Ewa O. (2019) Hepatotoxicity and histological evaluation of aqueous and methanolic leaf extracts of Thaumatococcus daniellii and Alchornea cordifolia in Wistar rat models. Modern Health Sci. 1(2): 42-45.

Oke I.A., Adeleye O., Dada O., Adeyemi O., Anyasor G.N. (2016) Phytochemical constituent and antioxidant activity of Thaumatococcus daniellii Benn (Benth.) leaves (food wrapper). Int. J. Pharm. Phytochem. Ethnomed. 2: 55-61.

Olasehinde T.A., Olaniran A.O., Anthony I., Okoh A.I. (2019) Phenolic composition, antioxidant activity, anticholinesterase potential and modulatory effects of aqueousextracts of some seaweeds on $\beta$-amyloid aggregation and disaggregation. Pharm. Biol. 57(1): 460-469.

Olorunnisola O.S., Adetutu A., Owoade A.O., Okoh O.O., Oyewo E.B., Adegbola P. (2016) Ethno pharmacological and in-vitro anti-diabetic study of some medicinal plants commonly used in Ogbomoso, South Western Nigeria. J. Appl. Biosci. 105: 10064-10084.

Olorunnisola O.S., Adetutu A., Popoola R.B., Owoade A.O., Adegbola P., Adesina B.T. (2017) Nephroprotective effect of ethanolic leaf extract of Thaumatococcus danielli (Benth.) in streptozotocin induced diabetic rats. Func. Foods Health Dis. 7(12): 923-935.

Olorunnisola O.S., Ajayi A.F., Adetutu A., Olorunfemi G.F., Owoade A.O., Adegbola P., Afolabi O.K. (2019) Antihyperglycaemic and mode of action of Thaumatococcus danielli (BENN.) BENTH ethanol leave extract in streptozotocin-induced diabetic rats. Asian J. Res. Med. Pharmacol. Sci. 6(2): 1-10.

Omisope O., Oladipo G.O., Nlekerem C.M., Ibukun E.O. (2016) In vivo adaptogenic lipidomics of essential oil extract of Thaumatococcus daniellii leaf. J. Nat. Sci. Res. 6(15): 134-140.

Onwuema I.C., Onochie B.E., Safowora E.A. (1979) Cultivation of T. daniellii - the sweetener. World Crops 3: 106-111.

Osuocha K.U., Okafor I.J., Nweke E.O. (2018) Evaluation of the mineral and vitamin compositions of leaves of Alchornea cordifolia and Thaumatococcus danielli. Asian J. Res. Biochem. 3(4): 1-6.

Oyeleke G.O., Adetoro R.O., Lawal R.T., Salam M.A. (2017) Some aspects of nutrient, antinutrient, minerals and sugars contents of Thaumatococcus danielli (Benn.). Seeds Adv. Res. 10(4): 1-7.
Oz A.T., Kafkas E. (2017) Phytochemicals in fruits and vegetables. [in:] Super food and functional food - an overview of their processing and utilization. In Tech: 175-184.

Pan S.Y., Litscher G., Zhou H.S., Yu F.S., Chen L.Z., Zhang Q.H., Tang F.S., Sun K.M., Ming N.J., KO M.K. (2014) Historical perspective of traditional indigenous medical practices: the current renaissance and conservation of herbal resources. Evid.-Based Compl. Alternative Med. 14: 1-20.

Parihar M.S., Parihar A., Fujita M., Hashimoto M., Ghafourifar P. (2009) Alpha- synuclein over expression and aggregation exacerbates impairment of mitochondrial functions by augmenting oxidative stress in human neuro-blastoma cells. Int. J. Biochem. Cell Biol. 41(10): 2015-2024.

Parmer V. (2005) Herbal medicine: its toxic effect and drug interactions. The Indian Anaesthetics' Forum: 1-9.

Phasomkusolsil S., Soonwera M. (2011) Efficacy of herbal essential oils as insecticide against Aedes aegypti (Linn.), Culex quinquefasciatus (Say) and Anopheles dirus (Peyton and Harrison). Southeast Asian J. Trop. Med. Public Health. 42: 1083-1092.

Priscilla H. (2013) The role of anti-obesity drugs in patients with type 2 diabetes. US Endocrinol. 9(2): 101-107.

Quang U.L., Horng L.L., Ming C.W., Thi H.N. (2018) Natural plant colorants widely used in Vietnam traditional food culture. J. Food, Nutr. Agric. 1(1): 40-46.

Quinones-Aquilar E.E., Ferra-Cerrato R., Gani, R.F., Fernandez L., Rodriguez V.R. (2003) Emergence and growth of maize in crude oil polluted soil. Agrociencia 37: 585-594.

Raimi O.G., Elemo B.O., Fatai A.A., Bankole H.A., Kazeem M.I., Banjoko A.O. (2011) Isolation and partial characterization of a protease enzyme from Thaumatococcus daniellii waste. Afr. J. Biotech. 10(16): 3186-3190.

Ravi L., Krishnan K. (2017) Cytotoxic potential of N-hexadecanoic acid extracted from Kigelia pinnata leaves. Asian J. Cell Biol. 12: 20-27.

Salavkar S.M., Tamanekar R.A., Athawale R.B. (2011) Antioxidant in skin ageing - future of dermatology. Int. J. Green Pharmacol. 5: 161-168.

Samadder A., Tarafdar D., Abraham S.K., Ghosh K., KhudaBukhsh A.R. (2017) Nano-pelargonidin protects hyperglycemic-induced L6 cells against mitochondrial dysfunction. Planta Med. 83: 468-475. doi: 10.1055/s-0043100017

Santos C.C., Salvadori M.S., Mota V.G., Costa L.M., Almeida G.G., Oliveira A.A., Costa J.P., Sousa D.P., Freitas R.M., Almeida R.N. (2013) Antinociceptive and antioxidant activities of phytol in vivo and in vitro models. Neurosci. J. Article ID 949452. doi.org/10.1155/2013/949452

Satyanarayana U., Chakrapani U. (2007) Biochemistry (with clinical concepts \& case studies). 3rd ed. New Delhi: Elsevier Health Sciences APAC.

Schmidt B.M., Ribnicky P.E., Lipsky I., Raskin I. (2007) Revisiting the ancient concept of botanical therapeutics. Nature Chem. Biol. 3(7): 360-366.

Seidl P.R. (2002) Pharmaceuticals from natural products: current trends. Anais Acad. Brasil. Cien. 74(1): 145-150. 
Seo E.J., Ngoc T.M., Lee S.M., Kim Y.S., Jung Y.S. (2012) Chrysophanol-8-O-glucoside, an anthraquinones derivative in rhubarb, has antiplatelet and anticoagulant activities. J. Pharmacol. Sci.118: 245-254.

Shalom C.N., Iheagwam F.N., Anichebem C.J., Ogunnaike G.B., Emiloju O.C. (2017) Antioxidant and biochemical evaluation of Thaumatococcus daniellii seeds in rat. J. Biol. Sci. 17(8): 381-387.

Shalom N.C., Adetayo Y.O., Samuel T.P., Bolaji J.D., Tamuno E. (2014) Analyses of the leaf, fruit and seed of Thaumatococcus danieeli (benth). Exploring potential uses. Pakistan J. Biol. Sci. 17(6): 849-854.

Shalom N.C., Franklyn N.I., Makinde B.T., Thorpe B.O., Emiloju O.C. (2018) Data on in vivo antioxidant, hypolipidemic and hepatoprotectivepotentialof Thaumatococcus daniellii (Benn.) Benthleaves. Data in Brief 20: 364-370.

Sharma S., Gupta P.C., Rap C.V. (2012) Nutrient content, mineral content and antioxidant activity of Amaranthus viridis and Moringa oleifera leaves. Res. J. Med. Plant 6(3): 253-259.

Shinde A., Ganu J., Naik P. (2012) Effect of free radicals \& antioxidants on oxidative stress. J. Dental Allied Sci. 1(2): 63-66.

Shrestha J.P., Fosso M.Y., Bearss J., Chang W.T. (2014) Synthesis and anticancer structure activity relationship investigation of cationic anthraquinone analogs. Eur. J. Med. Chem. 77: 96-102.

Shrestha J.P., Subedi Y.P., Chen L., Chang W.T. (2015) A mode of action study of cationic anthraquinones analogs. A new class of highly potent anticancer agents. MedChemComm. 6(11): 2012-2022.

Simone R., Subhash C.G., Madan M.C., Bharat B.A. (2010) Oxidative stress, inflammation and cancer: how are they linked? Free Radic. Biol. Med. 49(11): 1603-1616.

Soetan K.O., Akinrinde A.S., Ajibade T.O. (2013) Preliminary studies on the haematological parameters of cockerels fed raw and processed guinea corn (Sorghum bicolor). Proc. $38^{\text {th }}$ Annual Conf. Nigerian Soc. Animal Prod: 49-52.

Sofowora E.A. (1993) Medicinal plants and traditional medicine in Africa. Ibadan, Nigeria. John Wiley and Sons Ltd, Spectrum Books: 55-62.

Sotannde O.A., Oluwadare A.O. (2014) Fibre and elemental contents of Thaumatococcus daniellii stalk and its implications as a non-wood fibre source. Int. J. Appl. Sci. Technol. 4(1): 178-185.

Stamati K., Mudera V., Cheema U. (2011) Evolution of oxygen utilization in multicellular organisms and implications for cell signaling in tissue engineering. J. Tissue Eng. 2(1): 20-41. doi:10.1177/2041731411432365

Stanley P., Kamalakkannan N. (2006) Rutin improves glucose homeostasis in streptozotocin diabetic tissues by altering glycolytic and gluconeogenic enzymes. J. Biochem. Mol. Toxicol. 20: 96-102.

Stephen A.G., Powls R., Benon R.J. (1994) Cysteine protease activity in arils of Thaumatococcus daniellii: relationship between the sweet protein thaumatin and cysteine protease activity. lnt. J. Biochem. 26(7): 879-884.
Singh A., Kumar Y. (2018) Phytoremediation: cleaning environment using plants. Trends Plant Sci.13: 99-111.

Suffredini I.B., Sader H.S., Gonçalves A.G., Reis A.O., Gales A.C., Varella A.D., Younes R.N. (2004) Screening of antibacterial extracts from plants native to the Brazilian amazon rain forest and Atlantic forest. Brazil. J. Med. Biol. Res. 37: 379-384.

Sun T., Yan X., Guo W., Zhao D. (2014) Evaluation of cytotoxicity and immune modulatory activities of soyasaponin $A b$ : an in vitro and in vivo study. Phytomedicine 21: 1759-1766.

Tabuti J.Z.R.S. (2006) Herbal medicine used in the treatment of malaria in Budiope County,Uganda: a case study of Budiope County. J. Ethnopharmacol. 116: 33-42.

Termote C. (2012) Wild edible plant use in Tshopo District, Democratic Republic of Congo. PhD thesis. Faculty of Bioscience Engineering, University of Ghent, Belgium.

Thibado S.P., Thornthwaite J.T., Ballard T.K., Goodman B.T. (2018) Anticancer effects of Bilberry anthocyanins compared with Nutra Nano Sphere encapsulated Bilberry anthocyanins. Mol. Clin. Oncol. 8: 330-335.

Thorn B. (2004) Chefs find banana leaves appealing: natural food wrapper, an authentic way to showcase tropical, ethnic foods. Nation's Restaurant News.

Tomlison P.B. (1961) Morphological and anatomical characteristics of the Marantaceae. J. Linn. Soc. (Bot.) 58: 55-78.

Trinter I. (2007) African traditional healers: cultural and religious beliefs intertwined in a holistic way. South Afr. Pharmaceut. J. 74(8): 56-60.

Ukwubile C.A., Oise I.E., Nyiayem J.T. (2017) Preliminary phytochemical screening and antibacterial activity of Thaumatococcus daniellii (Benn.) Benth. (Marantaceae) leaf extract. J. Bacteriol. Mycol. 4(2): 1-5.

Vargas V.F., Ceja M.L. (2016) Sparteine as an anticonvulsant drug: evidence and possible mechanism of action. Seizure 39: 49-55.

Vellosa J.C., Regasini L.O., Khalil M.N., Bolzan V.D., Khalil O.A., Manente F.A., Nett HP., Oliveira M.M. (2011) Antioxidant and cytotoxic studies for kaempferol, quercetin and isoquercitrin Ecl. Quím 36(2): 7-20.

Waliszewski W.S., Oppong J.B., Sinclair F.L. (2005) Implications of local knowledge of the ecology of a wild supersweetener for its domestication and commercialization in West and Central Africa. Econom. Bot. 59(3): 231-243.

Watson L., Dallwitz M.J. (2000) The families of flowering plants: descriptions, illustrations, identification, and information retrieval. Version $27^{\text {th }}$ Sept. 2000; http: biodiversity.uno.edu/delta

Weiss T.J. (1983) Commercial oil sources in food oils and their uses. The AVI Publishing Co. Inc. Westport, Connecticut: 35-63.

WHO (1998) Regulatory situation of herbal medicines. $A$ worldwide review. Geneva, Switzerland: 1-5.

WHO (2002) Traditional medicine strategy 2002-2005. Geneva, Switzerland.

Wuthi-Udomlert M., Kupittayanant P., Gritsanapan W. (2010) In vitro evaluation of antifungal activity of anthraquinone derivatives of Senna alata. J. Health Res. 24(3): 117-122. 
Yang J., Guo J., Yuan J. (2008) In vitro antioxidant properties of rutin. LWT- Food Sci. Technol. 41: 1060-1066.

Yeboah S.O., Hilger T.H., Kroschel K. (2003) Thaumatococcus daniellii (Benth): a natural sweetener from the rain forest zone in West Africa with potential income generation in small scale farming. J. Appl. Sci. 6: 854-859.

Zemanek E.C., Wasserman B.P. (1995) Issues and advances in the use of transgenic organisms for the production of thaumatin, the intensely sweet protein from Thaumatococcus daniellii. Crit. Rev. Food Sci. Nutr. 35(5): 455-466.

Zhou Y.Q., Liu H., He M.X., Wang R., Zeng Q.Q., Wang Y., Ye W.C., Zhang Q.W. (2018a) A review of the botany, phytochemical and pharmacological properties of Galangal: greater galangal (Alpinia galanga (L.) Willd and lesser galangal (Alpinia officinarum Hance). [in:] Natural and artificial flavoring agents and food dyes. Academic Press: 357.

Zhou Z.C., Feng W.Q., Han Y., Zheng J., Chen T., We Y.Y., Gillings M., Zhu Y.G., Chen H. (2018b) Prevalence and transmission of antibiotic resistance and microbiota between humans and water environments. Environ. Int. 121(2): 1155-1161. 